\title{
Media in Croatia: from freedom fighters to tabloid avengers
}

\author{
Marijana Grbeša • Marija Volarević
}

Received: 13 June 2021 / Accepted: 31 July 2021 / Published online: 10 September 2021

(C) The Editors of the Journal 2021

\begin{abstract}
The article provides an overview of the Croatian media landscape and its transformation that has been driven by the processes of democratization, commercialization and digitalization.

The main media-related concerns from 1990 to 2000 were freedom of the press, autonomy of journalism and censorship. The liberalization of the media market that started in 2000, led to proliferation of media outlets and galloping commercialization of media ownership and content. The next big change came with digitalization that fundamentally altered media habits of Croatian audiences. Television was preceded by online media as the main source of news while the press registers constant decline in readership, trust and advertising revenues. Radio remains the most trusted medium, as opposed to social media that are the least trusted source of information. Nevertheless, the level of trust in social networks in Croatia is considerably higher than the EU average.

The data on media freedom and journalistic autonomy indicate that Croatia has made significant progress in this respect in the past thirty years. Although problems related to freedom, autonomy and political pressure persist, the biggest threat to journalism nowadays seems to come from within the profession. Commercialization, coupled with digitalization and merciless struggle for survival, eventually led news media to succumb to tabloid-style journalism and to radically downplay their professional standards. Although the role of the media as a social corrective remains undisputed, such media practices seem to cultivate 'media fatigue' and fos-
\end{abstract}

\footnotetext{
Dr. Marijana Grbeša $(\bowtie)$

Faculty of Political Science, Department of Strategic Communication, University of Zagreb, Lepušićeva 6, 10000 Zagreb, Croatia

E-Mail: grbesa@fpzg.hr

Marija Volarević

VERN University, Palmoticeva street 82/1, 10000 Zagreb, Croatia

E-Mail: marija.volarevic@vern.hr
} 
ter distrust in political institutions. In such an ethically challenging environment, the newsrooms and professional organizations remain for the most part silent about eroding professional standards.

Keywords Croatia $\cdot$ Democratization $\cdot$ Commercialization $\cdot$ Digitalization $\cdot$ Media trust $\cdot$ Journalistic standards

\section{Introduction}

The contemporary media system in Croatia has been decisively shaped by a turbulent historical, political and social framework, as well as by global changes in media and communications. The main lines of the media system (r)evolution in Croatia are congruent with the developments in other Central and Eastern European countries (CEE). Peruško et al. (2021, pp. 25-32) argue that media transformation in CEE has been fundamentally determined by four "critical junctures"-modernization, socialism, post-socialist democratization and the communication juncture. For Eastern Europe, the process of modernization stretches from the 19th century to the beginning of WWII, with two events being especially important - the invention of printing technology and the emergence of newspapers as the mass media (cf. Peruško et al. 2021, pp. 25-26). The second juncture was marked by the rise of socialism as the dominant political and economic paradigm in Eastern Europe. Peruško et al. (2021, p. 27) suggest that despite significant political, social and cultural differences between socialist countries during this period, media in Eastern Europe were commonly, but incorrectly, classified as belonging to a single "Soviet" media system (cf. Siebert et al. 1956). The third juncture marks the transition from socialism to democracy and has been the subject of most of scholarly work on media systems in Eastern Europe (cf. Dobek-Ostrowska 2015, 2019; Hallin and Mancini 2013; Herrero et al. 2017; Peruško 2013, 2016; Peruško et al. 2021). The last juncture is not a temporal phase but rather a series of global communication-related changes and convergences that stretch across different times and cover a wide range of processes, from the emergence of the new media technologies to the most recent changes covered by the concepts of digitalization, mediatization (cf. Lundby 2014), hybridity (cf. Chadwick 2017) and more.

In addition to these shared temporal stages and processes, the development of the contemporary media scene in Croatia was strongly influenced by the war for independence (the Homeland War, 1991-1995). During and after the war, the media were under the strong influence of the wartime president Franjo Tuđman and his party Croatian Democratic Union (Hrvatska Demokratska Zajednica, HDZ). Although Tuđman was hailed by many as "the leader who unified Croatia in 1991 and led the country to victory", by the end of the 1990s "many Croatians had grown weary of Tuđman's virulent nationalism" and "rampant corruption under his regime" (Freedom House 2000). International organizations were increasingly concerned about state censorship and the freedom of the media (cf. Fisher 2006). According to Segvić (2003, p. vi), in the 1990s, the media in Croatia went through three stages: the "Tumultuous Media" (1990-1994) when censorship was present but 
not entirely a component of the media; the "Veil of Censorship" (1995-1998) when state censorship was suffocating the media; and the "Recovery Period" (1999-2000) when the media began to experience more freedom. On the economic side, the media transition in the 1990s was characterized by "nationalization, privatization and marketization" (Peruško 2013, p. 714).

The events in the 1990s paved the way for the development of the contemporary media system which transitioned from authoritarian to the "polarized pluralist media system" characterized by the "weak and late development of the mass press, weak professionalization of journalism, strong political parallelism, and the strong role of the state" (Peruško 2013, p. 721). Despite its deficiencies, the Croatian media have played an important role in democratization of society since the 1990s. Jurić et al. (2020, p. 483) argue that the media in Croatia addressed more social issues than the institutions in charge and that the media have been acting as a constructive social corrective.

The goal of this paper is to provide an overview of the Croatian media milieu in relation to two critical junctures-post-socialist democratization and the most recent communication juncture. In the first section, we explain the historical background and contemporary characteristics of the media system in Croatia. Then we analyse the media market and discuss changes in the media landscape and audience habits that happened mostly because of pervasive commercialization and digitalization. Finally, we analyse the state of media freedom and professional standards in journalism and discuss how erosion of quality journalism in Croatia may have contributed to the decline of trust in media.

\section{The Croatian media system}

According to Peruško et al. (2021, p. 1), "the transformations of the media following the fall of socialism involved changes in the institutions-in the rules and values but also in the practices of media professionals (including journalists) and in the media-related practices of audiences". These changes in Croatia were consistent with political and social consolidation of the post-socialist society. Bilić (2012, pp. 828-829) identifies three transformative periods in the development of the Croatian media system. The first period lasted from 1990 to 1999 and was marked by state building and a monopoly of the national state television (Hrvatska televizija, HTV). The liberalization of the media market applied only to the press. The impact of the new technologies was only marginal. The second period, according to Bilić (2012), lasted from 2000 to 2003. It was characterized by structural political transformation and democratic consolidation, following the death of Franjo Tuđman in 1999. After Tuđman's departure, parties from the centre to the left joined into a large coalition led by the Social Democratic Party (Socijaldemokratska partija Hrvatske, SDP) to defeat the HDZ in the 2000 parliamentary election. Soon after, the semi-presidential system that granted Tuđman excessive power, was abandoned and replaced by a parliamentary system, leaving presidents primarily with ceremonial roles. The liberalization of television and the telecommunications market followed, along with the changes in the management of the state television, HTV, which started its trans- 
formation into a public television (cf. Peruško and Čuvalo 2014, p. 135). The first commercial television, Nova TV started broadcasting in 2000 and the second, RTL, in 2004 (cf. Peruško and Čuvalo 2014, p. 135). Finally, the third period started in 2004. Bilić (2012, p. 827) suggests that this period has been marked by harmonization of the national media legislation with the European Union provisions because of the country's accession to the EU, the growing importance of the Internet and an intensive penetration of "consumer and global pop-cultural products" into the Croatian media market.

The most diligent work on investigation and classification of the Croatian media system has been conducted by Peruško $(2013,2016)$ and Peruško et al. (2021). Peruško (2013) initially deployed Hallin and Mancini's (2004, 2012) conceptualization of the media systems to place Croatia within the "polarized pluralist Mediterranean model". Besides the characteristics of the "polarized pluralist" media market mentioned earlier, Peruško (2013, p. 721) argues that the Croatian political system displays characteristics of the "Mediterranean model" such as:

strong political clientelism and low implementation of rational legal authority, that is, the rule of law; a political culture that does not value adherence to abstract norms and does not easily differentiate between public and private interest; and elites who communicate more to each other than to citizens.

Although Hallin and Mancini's seminal work on three models of media and politics (2004) provides useful "empirical benchmark" for comparative media studies (Peruško et al. 2021, p. 3), it failed to grasp the specifics of the media systems outside of the Western Europe and North America, including the CEE countries. This has inspired several scholars to adapt Hallin and Mancini's typology and provide their own categorizations of the CEE media systems. Exceptionally relevant in this respect is the work of Herrero et al. (2017), Dobek-Ostrowska (2015) and Peruško (2013, 2016). Herrero et al. (2017) use four indicators (political parallelism, public broadcasting, press freedom and foreign ownership) to group CEE countries into three clusters: eastern, central and northern cluster (p. 4808). They position Croatia in the central cluster, which is located somewhere in the middle in terms of political parallelism and press freedom, but scores lower than the easter and northern clusters in terms of foreign media ownership and higher in terms of the relevance of PSB (cf. Herrero et al., p. 4810).

Dobek-Ostrowska (2015) identifies four models of media and politics in CEE: "the Hybrid Liberal", "the Politicized Media", "the Media in Transition" and "the Authoritarian model" (p. 25). According to her, Croatia belongs to the Politicized Media model, which is characterized by "low democratic standards and political culture of societies, a high politicization of public broadcasting service and control over public radio and television by political actors" (Dobek-Ostrowska 2015, p. 28). Peruško's (2016) adaptation of Hallin and Mancini's model includes four key indicators- "role of the state", "media market", "political and economic parallelism" and "professionalization of journalism" (p. 258). She applies these indicators to generate three media models that include both CEE and Western European countries- "The South/East European model", "The European mainstream model" and "The Nordic model" (Peruško 2016, p. 258). Croatia demonstrates features of "The South/East 
European" model, which is characterized by: "lower to medium quality of public television", "lower newspaper circulation", "higher party influence", "higher owner influence" and "lower professionalism and independence" of journalism (Peruško 2016, p. 258).

Although country placement in proposed media models is subject to modification because these models are based on dynamic categories, such as the freedom of the press, share of foreign media ownership, market volatility etc., they still provide a solid framework for understanding contemporary media market in Croatia.

\section{The Croatian media market}

The Croatian media market is diverse and competitive. The largest media owners in Croatia are foreign media corporations. The Austrian Styria Media Group owns two out of the three bestselling newspapers: the tabloid 24 sata (weekly use of 33\%, cf. Reuters Institute Digital News Report (RIDNR) 2021, p. 70) and the political, conservative leaning newspaper Večernji list (weekly use of 19\%, cf. RIDNR 2021, p. 70). Styria also publishes a daily Poslovni dnevnik, and a weekly 24 Express. Next to Styria, the largest share of the print media market is owned by Hanza Media, a company established by Marijan Hanžeković, a Croatian lawyer and entrepreneur. Hanza's media empire used to be owned by the Croatian company Europa Press Holding and German WAZ Mediengruppe (today Funke Mediengruppe). A financial crisis and bad business decisions pushed EPH to the brink of bankruptcy back in 2014, when it was acquired by Hanza Media. Hanza's flagship publication is a left leaning political daily, Jutarnji list, which, with its weekly use of $25 \%$ (cf. RIDNR 2021, p. 70), has the largest readership after Styria's tabloid 24 sata. Hanza Media also publishes a variety of other newspapers and magazines (Slobodna Dalmacija, Dubrovački vjesnik, Sportske novosti, Globus, Gloria etc.).

Styria and Hanza Media have the leading role in the digital media market as well. The online edition of 24 sata, 24sata.hr is the second-best online brand, with the weekly use of 57\% (cf. RIDNR 2021, p. 70). The online edition of Hanza's Jutarnji list, jutarnji.hr is the third most popular online media brand, with the weekly use of $48 \%$ (cf. RIDNR 2021, p. 70). At the top of the list of the most popular online media is Index.hr, a news site established by journalist Matija Babić in 2002 (weekly use of $64 \%$, cf. RIDNR 2021, p. 70). Index.hr is a tabloid-style news site that has a reputation of an independent, liberal, and strongly opposition outlet.

As for broadcasting, Croatian television (Hrvatska televizija, HTV) was the main source of information for Croatian citizens for many years (cf. Perišin 2013, p. 156). It is a successor of the socialist Television Zagreb (Televizija Zagreb) that started broadcasting in 1956 and that was part of the state broadcaster Radio Television Zagreb (Radiotelevizija Zagreb). In 1990 Croatian Parliament changed the name of the broadcaster to Croatian Radio Television (Hrvatska radiotelevizija, HRT). HRT is funded mainly through a monthly fee that is mandatory for anyone who lives in Croatia and owns a receiver that can transmit radio or audio-visual program. Commercial activities, such as advertising or commercial production, represent HRT's secondary source of funds. HTV today airs on five channels, HTV1, HTV2, HTV3, 
HTV4 and HTV international while Croatian Radio has three national channels, eight local and one international. According to the Agency for Electronic Media, there are 153 radio stations that broadcast in Croatia; most of them are commercially oriented and only eight are non-profit radio stations (cf. Mučalo 2020). ${ }^{1}$

In recent years, HTV ceased to be the main source of news in Croatia; it has been overtaken by Nova TV (cf. RIDNR 2021 and 2020) and RTL (cf. RIDNR 2021). Although HTV has undergone a transformation from state to public television, the controversies about whether it serves the public or the government still remain (cf. Šalković 2000; Zgrabljić Rotar 2003). The political influence over Croatian Television is being exercised mainly through the management which is appointed by Croatian Parliament. The Parliament elects the Director General to a five-year term. It also appoints four out of five members of the Supervisory Board and nine out of eleven members of the Program Council. The remaining members of the Supervisory Board and the Program Council are elected by the employees. The members of the management bodies are elected in government/opposition parity (cf. Peruško et al. 2021, p. 167).

The perception that the public service broadcaster has been the mouthpiece of the government is one of the reasons why HTV generates a rather high percentage of distrust (21\% of people who do not trust it, cf. RIDNR 2021, p. 70) compared to its competition, Nova TV (10\%, cf. RIDNR 2021, p. 70) and RTL (10\%, cf. RIDNR 2021, p. 70). The arrest of the HRT's director general Kazimir Bačić by an anti-corruption police under suspicion of financial meddling in cahoots with some members of the Zagreb city administration in June 2021, has probably further damaged the image of the public television. ${ }^{2}$ HRT has filed 35 lawsuits against journalists from different media who were allegedly slandering the public broadcaster. ${ }^{3}$

According to Milosavljević and Poler (2018, p. 1151) the development of the public service broadcasting in South-East Europe has been "widely seen as a failure". PSBs seem to have been unable to resist political and commercial grip and consequently have failed to "provide impartial news and quality programming" (p. 1151). Croatia is apparently not an exception.

The two largest commercial televisions that have replaced HTV as the most prominent sources of offline news in Croatia-Nova TV and RTL-are owned by foreign companies. Until 2017, Nova TV was owned by the Central European Media Enterprise (CME Group). Today it is owned by the United Group, whose owner is the British investment fund, BC Partners. The cable news channel N1 Croatia, whose viewership has been progressively rising, and the sports channel Sportklub are part of the same group. German RTL owns seven channels in Croatia: RTL, RTL 2, RTL Living, RTL Kockica, RTL Passion, RTL Crime and RTL Adria.

\footnotetext{
1 Agency for Electronic Media. https://pmu.e-mediji.hr/Public/PregledRadioNakladnici.aspx. Accessed 05 June 2021.

2 Reuters, https://www.reuters.com/world/europe/croatian-anti-corruption-police-arrest-state-tv-headmedia-2021-06-30/. Accessed 10 July 2021.

3 Croatian Journalists Association, HND, https://www.hnd.hr/broj-tuzbi-hrt-a-protiv-novinara-i-medija. Accessed 10 July 2021.
} 
The changes in the national and global media market, that went hand in hand with forceful technological changes, have fundamentally altered media habits of Croatian audiences. For instance, in 2010, television was the main source of news for the majority of Croatian citizens, while the Internet was the third most important, but at the same time, the most trusted source of information (cf. Brautović 2010). Today the situation is very different. According to the RIDNR (2021, p. 70), online media (including social media) are the most prominent source of news (for $88 \%$ of the respondents), television is second (for $75 \%$ of the respondents), social media are third (for 54\% of the respondents) and print media are the least prominent source of information (for $29 \%$ of the respondents). The most popular social network in Croatia is Facebook with $55 \%$ of people who use it for news and $72 \%$ of people who use it for news and other things. It is followed by YouTube, used by $26 \%$ of people for news and $71 \%$ of people for news and other content. The changing media habits have posed new challenges to the publishers and encouraged implementation of new business models, such as the introduction of different forms of paywall for digital content. Digital editions of the two leading political dailies, Jutarnji list and Večernji list have recently introduced a variant of a "soft paywall" (cf. Nenadić and Ostling 2018), which offers free access to a limited number of articles or charges for "the premium" content, such as interviews and columns. The transforming media landscape has also caused disruptions in advertising revenues. According to the Croatian Association of Communication Agencies (HURA 2020), the advertising expenditure has been increasingly shifting from traditional to digital media, although television remains the medium with the highest advertising revenue. In 2020, due to the COVID-19 pandemic, there was a decline in advertising in all media industries, compared to 2019. The lowest decline in advertising revenue was recorded in digital media $(-4 \%)$, and the highest in the press $(-31 \%)$.

Changes in media economy and media consumption do not necessarily converge with media trust. The research conducted by the European Broadcasting Union (2020), based on the 92nd Standard Eurobarometer Survey, indicates that $45 \%$ of Croatian citizens do not trust the media, which is above the EU average of $40 \%$. It is worth noting that Croatia is a country with very low trust in political institutions, one amongst the lowest in the EU (cf. Eurobarometer 2021; Henjak 2017). However, there are more people who still trust the media than those who do not (55\% compared to $45 \%$ ). Radio is the most trusted medium in Croatia (for $50 \%$ of citizens), as it is in the EU (57\%) as well. Social networks are the least trusted, with $32 \%$ of citizens who tend to trust them. However, the level of trust in social networks in Croatia is still much higher than in the EU, where the average trust is set at $20 \%$. The same goes for the Internet which is more trusted in Croatia (39\%) than in the EU (32\%). Conversely, the trust in traditional media in Croatia is below the EU average: $47 \%$ of Croatian citizens trust television, compared to $49 \%$ in the EU and $39 \%$ Croatian citizens trust the press, compared to $46 \%$ in the EU. The most trusted brands according to RIDNR (2021, p. 70) are Nova TV and RTL, trusted by $75 \%$ and $73 \%$, respectively. The least trusted brands are two tabloid news sites with a strong ideological slant, Index.hr with a strong liberal bias and Dnevno.hr with a clear right-wing agenda. 
What do these data tell us about the media market in Croatia? First, the shift from traditional to digital media as the main source of news is consistent with the changes of audience behaviour in other European countries (cf. RIDNR 2020, pp. 60-85, 2021, pp. 61-108). Second, trust in media and traditional media is below the EU average. This may be at least partly attributed to the general lack of trust in institutions in Croatia. However, trust in radio and television still precedes the trust in social networks and the Internet in general. Two commercial televisions have emerged as the most trusted brands while the public service broadcaster is lagging behind, burdened by the image of the government's "lap dog". Conversely, trust in the press has declined and is now levelled with the trust in the Internet. Such a position of the newspapers and magazines can possibly be explained by progressive tabloidization of their content (cf. Popović 2018; Vilović 2003) and more generally, by the digital turn in media industry that has encouraged audiences to stop buying newspapers and look for information online, where they are still available mostly for free (cf. RIDNR 2020, p. 10). The publishers have been trying to compensate for loss in newspaper readership by introducing paywalls to their digital editions. Third, the biggest distrust is being expressed about two online outlets that operate in ideologically charged and mutually conflicting bubbles. Index.hr is especially interesting in this respect because of the disparity between its popularity and trustworthiness. Finally, trust in the Internet and especially social media is considerably higher than the EU average. This may suggest that Croatian audiences might be more prone to consuming unverified information from unreliable sources; however, relevant research on spread and consumption of disinformation in Croatia is still not available (for perception of fake news in Croatia cf. Biloš 2020).

\section{Freedom of the media and quality of journalism}

The strategic implementation of the Croatian media policy began at the turn of the millennium, when the Ministry of Culture introduced the so-called "mini-media reforms" and proposed three new media laws: the Electronic Media Act, Media Act and Croatian Radio-Television Act (cf. Mučalo 2020, p. 92). Although institutions have been nominally devoted to promoting proliferation and diversity of media outlets and contents, Croatia has been facing challenges in terms of competitiveness and plurality of the media. In this respect, Peruško et al. (2011, p. 174) argue that in the countries where the state has ceased to insist on diversity and pluralism of the media through legislative framework, pluralism was soon reduced under the relentless influence of the media market.

Agency for Electronic Media (Agencija za elektroničke medije, AEM) is the institution officially tasked to promote media pluralism, public interest and media literacy and to ensure equal conditions for media development and media freedom. ${ }^{4}$ The agency manages the Fund for the Promotion of Pluralism and Diversity of Electronic Media. The Fund supports production and broadcasting of contents of public interest, such as the programs that promote national minorities' rights, edu-

\footnotetext{
${ }^{4}$ Agencija za elektroničke medije. https://www.aem.hr/. Accessed 10 July 2021.
} 
cation, science and arts. The Fund also supports community and indie media. Media pluralism is additionally encouraged through state subsidies to minority media and a reduced VAT on daily press (cf. Peruško et al. 2021, p. 154).

AEM's central body is the Council for Electronic Media (Vijeće za elektroničke medije, VEM) that controls Croatian broadcasting market. It is an independent regulatory body in charge of granting broadcasting concessions, revoking concessions and permits, supervising the implementation of provisions related to program established by law, overseeing the work of the Fund for the Promotion of Pluralism and Diversity of Electronic Media etc. The head of the Council is also the head of the AEM; he/she is appointed by Croatian Parliament. The role of the Agency is often seen as passive (cf. Peruško et al. 2021, p. 161) although it made several decisive moves that sparked huge public reaction, such as temporarily revoking the broadcasting licence to local televisions that promoted hate speech against migrants. ${ }^{5}$ The Agency is also very dedicated to promoting media literacy projects. Together with the UNICEF, it has launched one if the most comprehensive national initiatives for enhancing media literacy in Croatia. ${ }^{6}$

The most detailed assessment of the media pluralism in Croatia has been conducted by Bilić et al. (2021) as a part of the Media Pluralism Monitor, an ongoing project designed to measure "potential risks to media pluralism" in the EU member states. The Monitor uses four topics and accompanying indicators to measure risks: 1) "fundamental protection" (protection of freedom of expression and right to information, standards and protection in journalism, independence and effectiveness of the media authority, reach of traditional media and access to the Internet); 2) "market plurality" (transparency of media ownership, news media concentration, online platforms concentration and competition enforcement, commercial and owner influence over editorial content and media viability); 3) "political independence" (political independence of media, editorial autonomy, audiovisual media, online platforms and elections, state regulation of resources and support to media sector, independence of public service media) and 4) "social inclusiveness" (access to media for minorities, local/regional communities, women and community media, media literacy and protection against illegal and harmful speech) (Bilić et al. 2021, p. 4).

The results are presented on a scale from $0 \%-100 \%$, where scores between $0 \%$ and $33 \%$ are considered a low risk, $34 \%$ to $66 \%$ a medium risk and $67 \%$ to $100 \%$ a high risk. In 2021, the average result for "fundamental protection" across all indicators was $41 \%$, for "social inclusiveness" $61 \%$ and $61 \%$ for "political independence". All three results are assessed as a "medium risk" to media pluralism. However, "market plurality" scored $71 \%$, which was interpreted as a high risk. In conclusion, Bilić et al. (2021, p. 18) argue that "regulation of the media sector has been stagnant for years, which results in the deterioration of media pluralism". They particularly highlight the issues of "poor protection of journalistic profession and standards", a mounting number of "defamation charges against journalists", "polit-

\footnotetext{
5 Agencija za elektroničke medije. https://www.aem.hr/koncesije/vijece-za-elektronicke-medije-privremenooduzelo-koncesije-nakladnicima-televizija-zbog-govora-mrznje/. Accessed 10 July 2021.

6 Medijska pismenost. https://www.medijskapismenost.hr/kako-i-sami-sudjelujemo-u-sirenju-laznihvijesti/. Accessed 10 July 2021.
} 
ical interference without consideration of public interest", insufficient inclusion of women, unsatisfactory level of media literacy, political bias of the public service media and the lack of adequate policy or strategy related to online platforms (Bilić et al. 2021, p. 18).

In 2021, the World Press Freedom Index ranked Croatia 56th out of 180 countries in terms of media freedom. ${ }^{7}$ This is an improvement compared to 2020 when Croatia was ranked 59th. In this year's report, Freedom House classified Croatia as a "free country" with "highly polarized media" that are "generally free from overt political interference and manipulation". ${ }^{8}$ In their Country Report for Worlds of Journalism, Peruško et al. (2016) write that "the majority of journalists in Croatia declared a high degree of professional autonomy".

Despite a satisfactory level of freedom and journalistic autonomy, Reporters Without Borders still indicate considerable problems concerning media freedom and the status of journalists that are in line with the conclusions of the Media Pluralism Monitor: "'humiliating' media content has been criminalized since 2013," "the government has not stopped meddling in the public TV broadcaster HRT," "the Covid19 pandemic deepened the financial crisis in the media, leading many outlets to cut pay and stop using freelancers" and so on. ${ }^{9}$ Ivanuš (2021) conducted a survey among 141 journalists and editors from print, electronic and online media to examine their perception of the most important problems in the media. Most of the examined media professionals believe that political influence is the main problem (for $75.2 \%$ ). Political and commercial pressure on editors was indicated as a problem by $74.5 \%$ of respondents and the influence of different lobbies by $62.4 \%$. The economic crisis caused by Covid-19 was recognized as a considerable problem by $70.2 \%$ and low professional standards of journalists and editors by $53.9 \%$ of respondents. Tabloidization was accentuated by $45.7 \%$ and the influence of the owners by $44.7 \%$ of editors and journalists. The loss of public trust in media was identified as an issue only by $31.2 \%$ of respondents, which Ivanuš interprets as a sign that journalists and editors have come to terms with it (cf. Ivanuš 2021, pp. 84-85), i.e., that they have accepted distrust as a kind of a 'new normal' in journalism. Accepting the loss of trust in media as 'business as usual' is alarming, especially in the light of growing evidence about eroding quality of the media discourse in Croatia.

Digitalization, increased commercialization and introduction of sensationalism as a new norm in journalism, have negatively affected journalistic practices and professional standards of Croatian news media (cf. Hromadžić 2013; Labaš and Ciboci 2011; Švob-Đokić et al. 2011). Popović (2018, p. 40) asserts that "[c]ommodification of journalism has contributed to the erosion of the profession, since a large portion of media production can be considered neither an expert service, nor information of social importance and public interest". Popović substantiates this assumption with the results of the survey conducted by the Ministry of Culture among journalists and editors in 2013-2014, in which respondents indicated that "commercialization and

\footnotetext{
7 Reporters Without Borders, https://rsf.org/en/ranking. Accessed 22 May 2021.

8 World Press Freedom Index, https://freedomhouse.org/country/croatia/freedom-world/2021. Accessed 15 May 2021.

9 Reporters Without Borders, https://rsf.org/en/ranking. Accessed 22 May 2021.
} 
privatization of the media in Croatia had changed their modus operandi" and that "competition" and "the need to generate profit" had a great impact on journalism (Popović 2018, pp. 37-38). Grmuša and Prelog (2020) likewise suggest that digitalization has contributed to devaluation of professional standards. Croatian journalists who work in integrated newsrooms extensively rely on social media and digital sources in order to satisfy the "imperative of speed and exclusivity", which depreciates their professional standards (p. 76). In one of the first studies on the use of social networks as sources of news for traditional media, Volarević and Bebić (2013) found that Facebook and Twitter emerge as increasingly relevant sources for television news. Vesnic-Alujevic et al. (2020) revealed that in the 2015 and 2016 online news media in Croatia tended to heavily rely on Facebook as a source of political information. The most popular posts carried by the media belonged to politicians, which is at least partly due to the fact that their research covered the period surrounding the 2015 parliamentary election (p. 11). Today news media in Croatia, and especially online media, almost regularly use social media posts (Facebook, Twitter, Instagram) as a news source, often just by uncritically reporting or copy-pasting the content of the posts, which again raises the issue accountability (cf. Kovačić et al. 2019).

Another concern related to digital media is the disappearance of dealignment between professional and private use of social networks by journalists. In her analysis of the journalistic practices on Twitter in Croatia, Nenadić (2020, p. 142) establishes that "journalists in Croatia continue to recognise the traditional boundaries of their work into the social media realm, but they are adopting the cultures of self-expression and self-promotion in a way that sometimes deviates from organisational and institutional principles". Nenadić proposes the introduction of social media guidelines that would be drafted in partnership with journalists and would "serve as a means of self-regulation, or as an agreement between journalists and media organisations on what is desirable, and what would be counted as the potentially problematic use of social media" (Nenadić 2020, p. 52).

She quotes guidelines for Associated Press employees which "give order to refrain from declaring personal views on contentious public issues in any public forum, and forbid journalists from taking part in organized action in support of causes or movements" (Nenadić 2020, p. 68).

Media organizations in Croatia still have not proposed similar guidelines that would set the framework for professionally acceptable communication on social media, or, at least, these guidelines are not public. Nothing was proposed by the Croatian Journalists' Association either, although it is a professional association tasked to deal with ethics, among other things. The self-regulating mechanisms of the media in Croatia are generally very vague. The main self-regulatory body is the Journalists' Ethics Council (Novinarsko vijeće časti) which works within Croatian Journalists' Association. It acts upon individual complaints against journalists and media but it rarely self-initiatively reacts to breaches of ethics or unprofessional conducts of journalists, editors or media outlets. The conclusions of the Council are 
publicly available on its website. ${ }^{10}$ Ivanuš (2021, pp. 87-88) warns that $44.7 \%$ of journalists included in her survey claimed that they are not sufficiently familiar with self-regulation (55.3\% think that they are), while $60.3 \%$ believed that they do not have enough information about the importance of self-regulation.

All these developments have, to some extent, contributed to 'media fatigue' that was captured by the Reuters Institute Digital News Report in 2019. The report revealed that the strongest media avoidance, i.e., the percentage of people who "found themselves actively trying to avoid the news" was measured in Croatia $(56 \%) .{ }^{11}$ The report does not provide reasons for news avoidance in Croatia, but it does provide reasons for news avoidance in the UK, where avoidance was at $35 \%$. Most of the UK respondents said that they were avoiding the news because they "had a negative impact on their mood", that "there was nothing they could do to influence the events" and that they "can't rely on it to be true" (RIDNR 2019, p. 26). However, another research by the scholars from the Faculty of Political Science in Zagreb conducted within the "JOURLAB" project, revealed that people who, consciously or unconsciously, tend to avoid the news in Croatia do so because the news are too negative and encourage conflicts and tensions in society. ${ }^{12}$ Another recently obtained data also points to a complex relationship between Croatian media and the public. The latest Reuters Institute Digital News Report (2021, pp. 48) shows that impressive majority of Croatian respondents (75\%) are not concerned about the financial state of commercial news organizations in the country, while only $15 \%$ are concerned and $9 \%$ do not know. Likewise, only $28 \%$ think that government should step in to help commercial news organisations that face financial issues, $47 \%$ that it should not and $25 \%$ do not know. This may mean that Croatian public has embraced market logic and believes that survival of the news organizations should entirely depend on their performance in the media market. It may also mean that the public believes that the contents provided by commercial news media are not worth the public money.

Negativity, as one of the most prominent features of political news coverage in Croatia (cf. Grbeša and Šalaj 2018, p. 167) is very often embedded in a populist narrative, characterized by a Manichean rift between "ordinary people" and "corrupt elites". Media actively side with "the people" against the establishment, which may be interpreted using Strömbäck and Esser's (2009) "media interventionism" thesis. They argue that media interventionism refers to "a media-centered political reporting style in which, increasingly, journalists and media actors become the stories' main newsmakers rather than politicians or other social actors" (Strömbäck and Esser

\footnotetext{
${ }^{10}$ Croatian Journalists' Association. https://www.hnd.hr/zakljucci-novinarskog-vijeca-casti?seo=zakljuccinovinarskog-vijeca-casti. Accessed 10 July 2021.

11 The RIDNR is based on a survey of more than 75,000 peo ple in 38 markets, along with additional qualitative research. Europe remains a key focus, with 24 countries included but the survey also covers six markets in Asia (Japan, South Korea, Taiwan, Hong Kong, Malaysia, Singapore) plus Australia, four in Latin America (Brazil, Argentina, Chile, and Mexico) plus the United States and Canada.

12 The research was funded by Croatian Science Foundation (HRZZ) and it was conducted on a representative sample of 1009 respondents. The preliminary results of the research are available at https://www. medijskapismenost.hr/istrazivanje-o-medijskim-navikama-i-povjerenju-u-medije-i-novinare/. Accessed 10 July 2021.
} 
2009 , p. 217). They refer to the seminal study by Blumler and Gurevitch (1995) about the crisis of public communication in which Blumler and Gurevitch claim that "journalistic attitudes toward interventionism thrive in political cultures where public opinion is more cynical and distrustful of political institutions" because a climate is created in which "adversarial journalism seems socially acceptable" (p. 218). Although the presence of "adversarial journalism" is hard to miss by anyone who consumes Croatian news, the explicit implementation of this principle was observed by Peruško et al. (2016, pp. 2-3) who report that certain percentage of Croatian journalists justifies the use of controversial reporting methods, such as the use of documents without authorization (55.9\% of respondents), dramatization $(59.5 \%)$, illicit recording $(52.9 \%)$ etc. if it serves a greater good.

While the situation in which journalists acquire the role of 'avengers' possibly enhances their 'watchdog' role in ensuring the accountability of the government, it also probably enhances public cynicism and further depreciates already low trust in institutions.

\section{Conclusion}

The evolution of the contemporary media landscape in Croatia began in the 1990s and since then it has gone through several transformations. The first phase was the adjustment from socialism to democracy, which took place in peculiar circumstances of war and the post-war rigid governance of Franjo Tuđman. The main media-related concerns from 1990 to 2000 were freedom of the press, autonomy of journalism and censorship. After Tuđman's death in 1999 and the beginning of political democratization of the country in 2000, liberalization of the media market led to proliferation of media outlets and galloping commercialization of media ownership and content. The turn of the century was marked by the introduction of several media laws, designed to set a regulatory framework for the Croatian media market. The advent of two commercial televisions, Nova TV in 2000 and RTL in 2004 terminated information supremacy of HRT, the state radio-television that was transformed into a public service broadcaster. This early period set the foundations for the emergence of the media system that matches the characteristics of the "polarized pluralist Mediterranean model" (Hallin and Mancini 2012; Peruško 2013) and related "South/East European model" (Peruško 2016). Both models basically imply significant influence of politics and owners on media, lower professional standards in journalism, compromised journalistic autonomy and political servility of the public service broadcaster.

The next big change came with digitalization that caused tectonic changes in media and communications worldwide. The digital turn fundamentally altered media habits of Croatian audiences. In recent years, television was preceded by online media as the main source of news while the press registers constant decline in readership, trust and advertising revenues. Radio remains the most trusted medium, which is line with the trend in other European countries. The commercial televisions, Nova TV and RTL, firmly hold the status of the most trusted media brands. Social media are the least trusted source of information but the level of trust in social 
networks in Croatia is considerably higher than the EU average. This should raise concerns about media literacy of Croatian audiences and their capacity to resist disinformation. This should also encourage research on information disorder and fake news consumption in Croatia that is, unfortunately, still largely missing.

The data on media freedom and journalistic autonomy indicate that Croatia has made significant progress in the past thirty years. International organizations concerned with political, media and civic freedoms mostly regard Croatia as a "free country" today. Nevertheless, they also continuously warn about recurring political pressure on journalists and editors, political bias of public television and the threat of economic insecurity that many journalists experience. The same problems were identified by the Media Pluralism Monitor that assess Croatia as a country with "medium risk" for media pluralism. Besides, the Monitor insists on protection of journalists against defamation, political independency of Croatian Radio Television, strengthening of media literacy and introduction of meaningful policies related to online platforms.

Although problems with freedom and autonomy still largely persist, the biggest threat to journalism nowadays seems to come from within the profession. Commercialization, coupled with digitalization and merciless struggle for survival, eventually led news media to succumb to tabloid-style journalism and to radically downplay their professional standards. This unfortunate trend was recognized by scholars and media workers alike. According to several studies conducted in Croatian newsrooms, journalists seem to be aware of the erosion of journalistic standards but also seem to accept it as the 'new normal'. Moreover, they have upgraded their 'watchdog' role by adopting an "adversarial" populist narrative in which the media side with honest people against corrupt elites. This narrative permeates Croatian media discourse and is characterized by excessive cynicism and negativity in political reports. Although the role of the media as a social corrective remains undisputed, the increasing transformation of the media from freedom fighters into tabloid avengers, seems to cultivate 'media fatigue' and further distrust in political institutions. In such an ethically challenging environment, Croatian newsrooms and professional organizations remain for the most part silent about eroding professional standards.

\section{References}

https://freedomhouse.org/report/freedom-world/freedom-world-2000. Accessed 15 May 2021.

Bilić, P. (2012). Hrvatski medijski sustav između refleksivne modernizacije i medijatizacije: societalna i institucionalna analiza. Društvena istraživanja, 21, 821-842.

Bilić, P., Valečić, M., \& Prug, T. (2021). Monitoring media pluralism in the digital era. Application of the media pluralism monitor in the European Union, Albania, Montenegro, the Republic of North Macedonia, Serbia \& Turkey in the year 2020. https://cadmus.eui.eu/bitstream/handle/1814/71940/ croatia_results_mpm_2021_cmpf.pdf?sequence=1\&isAllowed=y. Accessed 25 July 2021 .

Biloš, A. (2020). Izazovi internetskog informacijskog prostora: kako stanovnici Republike Hrvatske doživljavaju problem lažnih vijesti. CroDiM, 3(1), 166-185.

Blumler, J., \& Gurevitch, M. (1995). The crisis of public communication. London: Routledge.

Brautović, M. (2010). Razvoj hrvatskog online novinarstva 1993-2010. Medianali, 4(8), $23-42$.

Chadwick, A. (2017). The hybrid media system: Politics and power (2nd edn.). Oxford: Oxford University Press. 
Dobek-Ostrowska, B. (2015). 25 years after communism: Four models of media and politics in Central and Eastern Europe. In B. Dobek-Ostrowska \& M. Glowacki (Eds.), Democracy and media in Central and Eastern Europe 25 years on (pp. 11-45). Frankfurt: Peter Lang.

Dobek-Ostrowska, B. (2019). How the media systems work in Central and Eastern Europe. In E. Połońska \& C. Beckett (Eds.), Public service broadcasting and media systems in troubled European democracies (pp. 259-278). Cham: Palgrave Macmillan.

Eurobarometer (2021). Standard Eurobarometer 94. Kantar. https://europa.eu/eurobarometer/surveys/ detail/2355. Accessed 22 May 2021.

European Broadcasting Union (2020). Market insights. Trust in Media., EBU. https://www.ebu.ch/ publications/research/login_only/report/trust-in-media.

Fisher, S. (2006). Political change in post-communist Slovakia and Croatia: From nationalist to Europeanist. New York: Palgrave Macmillan.

Freedom House (2000). Freedom in the World 2000. https://freedomhouse.org/report/freedom-world/ freedom-world-2000. Accessed 15 May 2021.

Grbeša, M., \& Šalaj, B. (2018). Dobar, loš ili zao? Populizam u Hrvatskoj. Zagreb: Tim Press.

Grmuša, T., \& Prelog, L. (2020). Uloga novih tehnologija u borbi protiv lažnih vijesti-iskustva i izazovi hrvatskih medijskih organizacija. Media studies, 11(22), 62-80.

Hallin, D. C., \& Mancini, P. (2004). Comparing media systems: Three models of media and politics. Cambridge: Cambridge University Press.

Hallin, D.C., \& Mancini, P. (2012). Comparing media systems beyond the Western world. Cambridge: Cambridge University Press.

Hallin, D.C., \& Mancini, P. (2013). Comparing media systems: between Eastern and Western Europe. In P. Gross \& K. Jakubowicz (Eds.), Media transformations in the post-communist world: Eastern Europe's tortured path to change (pp. 15-33). Plymouth: Lexington Books.

Henjak, A. (2017). Institutional trust and democracy satisfaction in Croatia: Partisanship- versus outcomedriven evaluations. Hrvatska i komparativna javna uprava, 17(3), 343-363.

Herrero, L. C., Humprecht, E., Engesser, S., Brüggemann, M., \& Büchel, F. (2017). Rethinking Hallin and Mancini beyond the West: an analysis of media systems in Central and Eastern Europe. International Journal of Communication, 11, 4797-4823.

Hromadžić, H. (2013). Politika, društvo spektakla i medijska konstrukcija realnosti. Politička misao, 50(2), $60-74$.

Ivanuš, Ž. (2021). Novinarska etičnost pod pritiskom interesnih skupina-iskustva hrvatskih novinara. Media, Culture and Public Relations, 12(1), 73-90.

Jurić, T., Kardaš, L., \& Bakota, A. (2020). Media analysis of online media contents on the phenomenon of current emigration from Croatia. Crkva u svijetu, 55, 453-494.

Kovačić, S., Musa, I., \& Tomić, Z. (2019). Online mediji i novinarstvo na društvenim mrežama-istraživanje na primjeru društvene mreže Facebook. Hum: časopis Filozofskog fakulteta Sveučilišta u Mostaru, 14(22), 7-28.

Labaš, D., \& Ciboci, L. (2011). Afera Indeks-u središtu pozornosti medija i javnosti. Medianali, 5(9), 140.

Lundby, K. (2014). Mediatization of Communication: Handbooks of Communication Science. Berlin: De Gruyter Mouton.

Media, H. U.R. A. (2020). Praćenja medijskog pluralizma. https://hura.hr/istrazivanja/medijska-potrosnjau-hr/. Accessed 22 May 2021.

Milosavljević, M., \& Poler, M. (2018). Balkanization and pauperization: Analysis of media capture of public service broadcasters in the Western Balkans. Journalism, 19, 1149-1164.

Mučalo, M. (2020). Komercijalni fm radio u kontekstu hrvatske medijske politike. Media studies, 11(21), 87-103.

Nenadić, I. (2020). Twitter and changing journalistic practice in Croatia. Doctoral Thesis. Josip Juraj Strossmayer Doctoral School. Osijek: University of Osijek.

Nenadić, I., \& Ostling, A. (2018). Media innovation in Europe and reinvention of audiences: Between citizens and consumers. Media Studies, 9(17), 4-22.

Perišin, T. (2013). Convergence journalism and the public interest: The case of Croatian Public Radio Television (HRT). Politička misao, 50(5), 155-172.

Peruško, Z. (2013). Rediscovering the Mediterranean characteristics of the Croatian media system. East European Politics and Societies, 27, 709-726.

Peruško, Z. (2016). Historical institutionalist approach in comparative media systems research: The case of post-Yugoslavia. Javnost-The Public, 23, 255-272. 
Peruško, Z., \& Čuvalo, A. (2014). Comparing socialist and post-socialist television culture: Fifty years of television in Croatia. View-Journal of European Television \& Culture, 3(5), 131-150.

Peruško, Z., Perišin, T., Topić, M., Vilović, G., \& Rotar, Z. N. (2011). Hrvatski medijski sustav prema UNESCO-vim indikatorima medijskog razvoja. Zagreb: Biblioteka hrvatska politologija, Fakultet političkih znanosti.

Peruško, Z., Vozab, D., \& Čuvalo, A. (2021). Comparing post-socialist media systems: The case of Southeast Europe. Abingdon: Routledge.

Peruško, Z., Čuvalo, A., \& Vozab, D. (2016). Country report. Journalists in Croatia. The worlds of journalism study. https://epub.ub.uni-muenchen.de/29703/1/Country_report_Croatia.pdf. Accessed 10 May 2021.

Popović, H. (2018). Journalism in Croatia in the Southeast European context: Deterioration of the 'professional project'. Work Organisation, Labour and Globalisation, 12(1), 25-42.

RIDNR/Reuters Institute (2019). Digital news report. https://www.digitalnewsreport.org/survey/2019/. Accessed 22 May 2021.

RIDNR/Reuters Institute (2020). Digital news report. https://reutersinstitute.politics.ox.ac.uk/sites/default/ files/2020-06/DNR_2020_FINAL.pdf. Accessed 22 May 2021.

RIDNR/Reuters Institute (2021). Digital news report. https://reutersinstitute.politics.ox.ac.uk/digitalnews-report/2021. Accessed 20 July 2021.

Šalković, H. (2000). Hrvatska televizija u transformaciji prema modelu javne televizije-iluzija ili realnost? Medijska istraživanja, 6(1), 19-39.

Segvić, I. (2003). Government and the freedom of the press: An 11-year content analysis of three Croatian newspapers. Doctoral thesis. Austin: University of Texas.

Siebert, F., Peterson, T., \& Schramm, W. (1956). Four theories of the press: The authoritarian, libertarian, social responsibility, and Soviet communist concepts of what the press should be and do. University of Illinois: Urbana.

Strömbäck, J., \& Esser, F. (2009). Shaping politics: Mediatization and media interventionism. In K. Lundby (Ed.), Mediatization. Concept, changes, consequences (pp. 205-224). New York: Peter Lang.

Švob-Đokić, N., Bilić, P., \& Peruško, Z. (2011). Does mediapolicy promote media freedom and independence? The case of Croatia. https://www.eliamep.gr/wp-content/uploads/2012/02/Croatia.pdf. Accessed 22 May 2021

Vesnic-Alujevic, L., Jurišić, J., \& Bonacci, D. (2020). Changing sourcing practices: Journalists' use of Facebook in Croatia. Journal of Applied Journalism \& Media Studies. https://doi.org/10.1386/ajms_ 00034

Vilović, G. (2003). Istraživačko novinarstvo, tabloidizacija i etika. Društvena istraživanja, 12, 957-974.

Volarević, M., \& Bebić, D. (2013). Social networks as news sources in Croatia's most viewed television newscasts. Media Studies, 4(8), 60-75.

Zgrabljić Rotar, N. (2003). Hrvatska medijska politika i javni mediji. Medijska istraživanja, 9(1), 59-75.

Dr. Marijana Grbeša is an Associate Professor at the University of Zagreb (Croatia), Faculty of Political Science, Department of Strategic Communication.

Marija Volarević is a University Lecturer at VERN' University of Applied Sciences in Zagreb (Croatia). 